\title{
A preliminary assessment of genetic relationships among agronomically important cultivars of black pepper Nisha Joy ${ }^{1}, Z_{\text {Abraham }}^{2}$ and EV Soniya*1
}

Address: ${ }^{1}$ Plant Molecular Biology Lab, Rajiv Gandhi Centre for Biotechnology, Poojappura, Thiruvananthapuram-695014, India and ${ }^{2}$ National Bureau of Plant Genetic Resources, Regional Station, Vellanikkara, Trichur-680654, India

Email: Nisha Joy - nishajoy2@hotmail.com; Z Abraham - nbpgrtsr@gmail.com; EV Soniya* - soniyaev@yahoo.com

* Corresponding author

Published: 29 June 2007

BMC Genetics 2007, 8:42 doi:10.1186/I47|-2156-8-42
Received: 3 October 2006

Accepted: 29 June 2007

This article is available from: http://www.biomedcentral.com/I47I-2I56/8/42

(c) 2007 Joy et al; licensee BioMed Central Ltd.

This is an Open Access article distributed under the terms of the Creative Commons Attribution License (http://creativecommons.org/licenses/by/2.0), which permits unrestricted use, distribution, and reproduction in any medium, provided the original work is properly cited.

\begin{abstract}
Background: The impact of diseases such as Phytophthora foot rot and the replacement of unproductive cultivars by high yielding ones has brought about the disappearance of varieties in Piper species, like any other crop. Black pepper (King of spices), is a major spice crop consumed throughout the world. It is widely cultivated across various parts of the world apart from India. The different cultivars may be genetically related and could be a source of valuable genes for disease resistance and an increase in quantity and quality. Even though Western Ghats in India is believed to be the site of origin of this crop, numerous accessions from the NBPGR have not yet been evaluated. Our study aims to investigate the genetic relatedness in major cultivars of black pepper using Amplified Fragment Length Polymorphism.

Results: Amplified Fragment Length Polymorphic (AFLP) DNA analysis was performed in thirty popular cultivars of black pepper from National Bureau of Plant Genetic Resources (NBPGR), India. Fingerprint profiles were generated initially with, five different primer combinations, from which three primer pair combinations (EAGC/MCAA, EAGG/MCTA and EAGC/MCTG) gave consistent and scorable banding patterns. From 173 scorable markers, 158(> 90\%) were polymorphic which shows there is considerable variation in the available germplasm. The dendrogram derived by unweighted pair group method analysis (UPGMA) grouped the accessions into three major clusters and four diverse cultivars with only $30 \%$ similarity. Karimunda, a widely grown and popular cultivar was unique in the fingerprint profiles obtained.

Conclusion: There are currently few fingerprinting studies using the valuable spice crop black pepper. We found considerable genetic variability among cultivars of black pepper. Fingerprinting analysis with AFLP proved to be an ideal tool for cultivar identification and phylogenetic studies. It shows the high level of polymorphism and the unique characterization of the major cultivars. An extensive range of similarity value between the cultivars was noted (6.0I to 98.13). Further screening of more cultivars will provide valuable information for current breeding programmes.
\end{abstract}

\section{Background}

The Piper genus includes the most valuable economically important spice crop, black pepper (Piper nigrum L) the
'King of Spices' which is consumed throughout the world. Apart from Asian countries such as Malaysia, India, Indonesia, Thailand, Vietnam, China and SriLanka, it is also 
cultivated in Brazil and Madagascar. The humid climatic conditions and the daily consumption in the diet made this spice crop a synonym of the Asian continent. The Western Ghats of Indian peninsula is the primary centre of origin of the 'King of spices' (Piper nigrum L), the source of medicinally and commercially important black pepper [1]. By habit, it is a perennial woody climber. Kerala the southernmost state of India occupies a considerable portion of the Western Ghats and is a rich source of wild relatives of this spice crop. The hot and humid climate of the sub-mountainous tracts of Western Ghats is ideal for its cultivation and hence Kerala is the centre for the production of most of the black pepper in India.

Cytological studies [2-4] suggest that the basic chromosome number of Piper is $\mathrm{x}=13$, whereas Piper nigrum is tetraploid $(2 \mathrm{n}=52)$. Chance cross-pollination between different species of Piper might have occurred when more than one species climbed up the same support trees. Due to the absence of a pollen transfer mechanism, subsequent gene flow is restricted in these progenies. High successful vegetative propagation ensures further survival and spread of these progenies. The present day Piper nigrum cultivars are the descendants of such segregating populations which are vegetatively propagated by farmers through cuttings [1]. Breeding and conservation programmes by humans based on good fruit set, pungency etc, contributes to cultivar diversity.

Amplified Fragments Length Polymorphism (AFLP) is an accepted tool among molecular biologists owing to its high resolution, wide genome coverage and reproducibility. AFLP is a novel PCR based assay [5] for plant DNA fingerprinting that reveals significant levels of DNA polymorphism. Genetic diversity studies by AFLP analysis have been applied to several accessions of plant genera like South Indian tea [6], Brassica [7], potato [8], soyabean [9], barley [10], wheat [11], marijuana [12], lupines [13], and opium poppy [14]. Awareness of genetic diversity among the available germplasm is a worthy pre-requisite for crop improvement programmes. To date, little work has been published in fingerprinting studies of black pepper except for Randomly Amplified Polymorphic DNA (RAPD) markers [15]. Even though RAPDs' generate polymorphic markers with random primers, the technique suffers from irreproducibility between laboratories $[16,17]$. The objective of the present study was to assess the usefulness of AFLP for cultivar identification and to determine genetic relationships of important cultivars of Piper nigrum.

\section{Results}

AFLP analysis generated a large number of reproducible and unambiguous markers for fingerprinting the cultivars of black pepper used in the study. Initially DNA finger- prints were created using five different AFLP primer combinations, from which three were selected for analysis. The three primer pair combinations (EAGC/MCAA, EAGG/MCTA and EAGC/MCTG) resolved 173 markers that could be scored reliably. Across all the thirty cultivars evaluated, 158 markers $(91.4 \%)$ were polymorphic. The details of the bands scored for further analysis with different primer combinations are illustrated in Table 1. A similarity matrix (Figure 2 and see Additional file 1 ) and a UPGMA dendrogram (Figure $3 a$ and $3 b$ ) were generated from the AFLP analysis software (Bionumerics software package, version 3.0, Applied Maths, Belgium). The dendrogram (Figure 3b) shows three main clusters (I, II and III) and four genetically distinct cultivars. The majority of

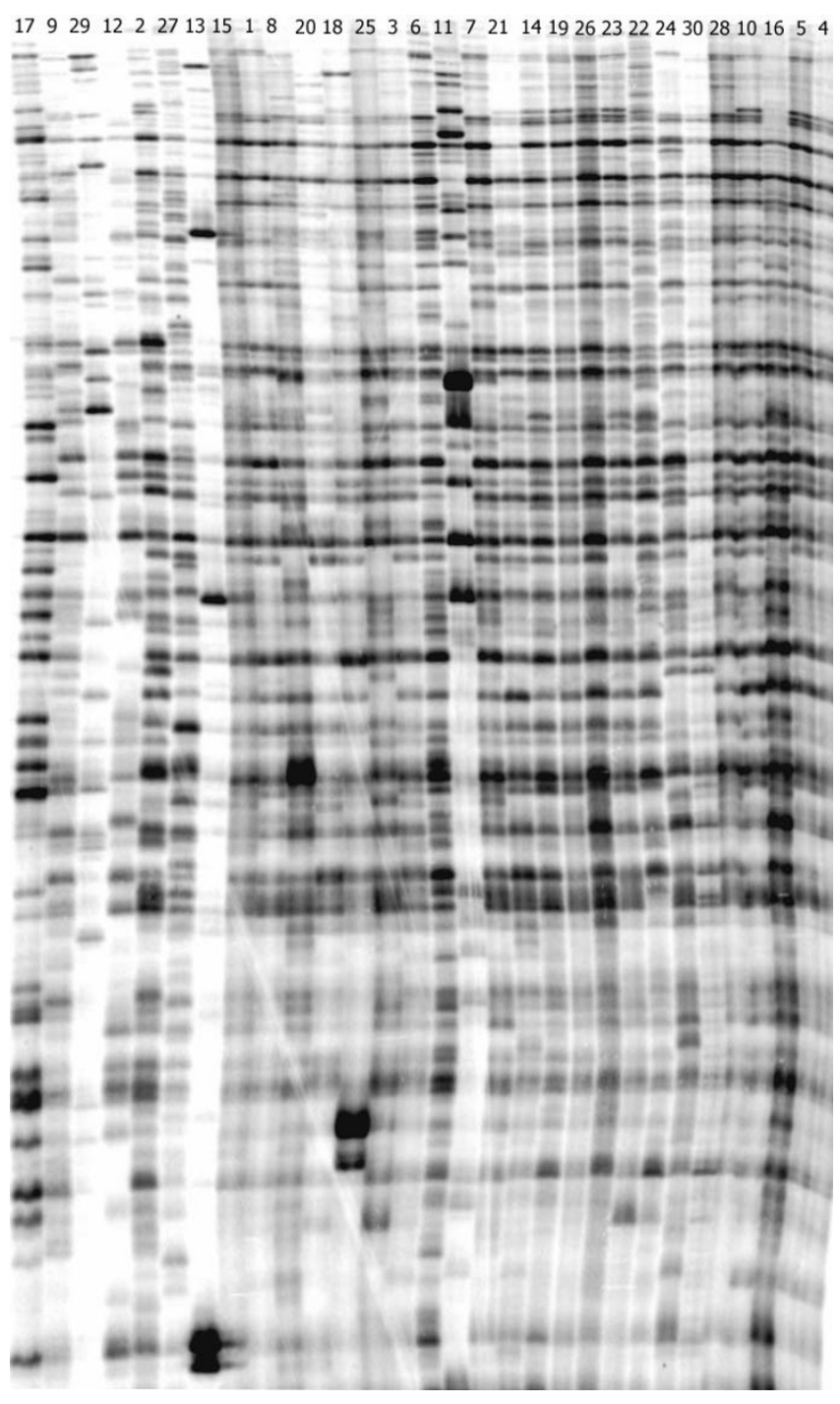

Figure I

AFLP profile obtained for the black pepper accessions (the number correspond to the serial number as in Table I, indicative of the cultivars). 


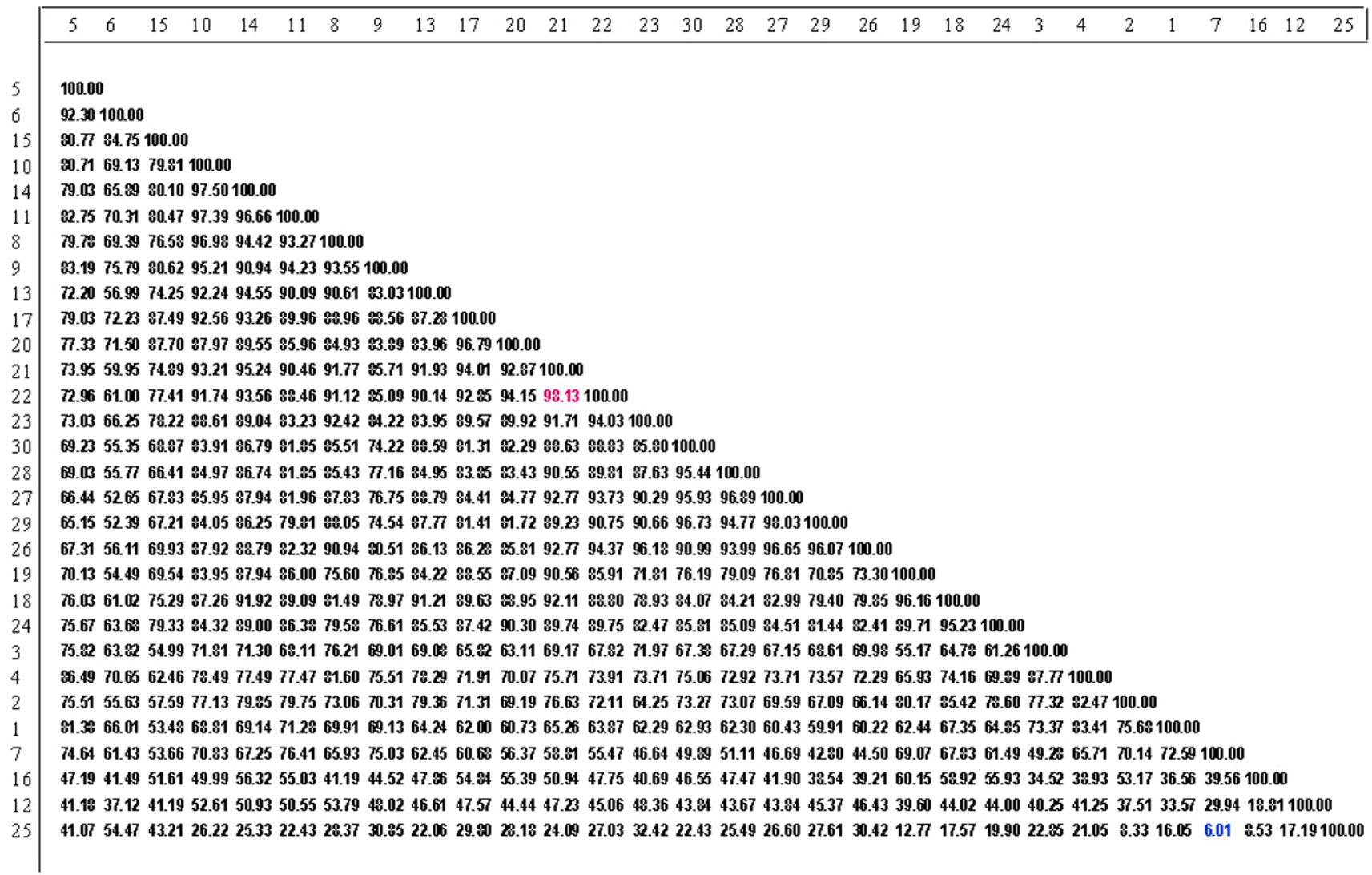

\section{Figure 2}

Matrix showing similarity value between the black pepper cultivars (numbers on the left and right border correspond to the serial number as in table I, indicating the cultivars).

the cultivars fall into cluster II, which can be further divided into four groups.

Our results show that cultivars with the same name from different localities do not always group together. The Vellamundi accessions 14 and 11 are from different localities; both are in cluster II, group1 and have a similarity coefficient of 96.6. Similarly, the Neelamundi accessions 10 and 17 have high similarity (92.56), although they occur in different groups within cluster II. The Thevanmundi accessions 12 (unique) and 15 (cluster I) have a similarity coefficient of 41.19. Likewise, the Karimunda accessions 3 (cluster III) and 16 (unique) have low genetic similarity (34.52). Morphological studies [1] found that the Karimunda cultivar (from Kerala) had distinctive leaf anatomical and stomatal characters. Accession 16 is most dissimilar from the rest and therefore may be a candidate for the "true" Karimunda. Regardless of names, the genetic distinctiveness of accession 16 makes it potentially more interesting for breeding programmes.
Our cluster analysis reveals four distinctive cultivars, accession 7 (local e), 16 (Karimunda), 12 (Thevanmundi) and 25 (Konnamankara). In our results, cultivars from the same locality mostly cluster together - eg. Cluster II, group 3 is made up of cultivars from Panniyur, all of the cultivars from Nedunkandam are in Cluster II, group 1, the Kochandi and Konni cultivars are together in cluster II, group 2, the Puyamkutti cultivars are together in cluster III.

AFLP analysis can provide information about locally derived (unnamed) cultivars. In our results, the local accessions mostly cluster with named accessions, except for local e, which is apparently not closely related to any of the other cultivars. Analysis of further accessions, particularly from the Ayiram Acre locality will help determine whether this cultivar is really genetically unique.

Morphologically the cultivars Kuching (29), Vattamundi (9), Kottanadan (28) and Thevanmundi (12 or 15) have been found to be similar $[18,19]$. Our AFLP analysis shows that Kuching (29), Vattamundi (9), Kottanadan 


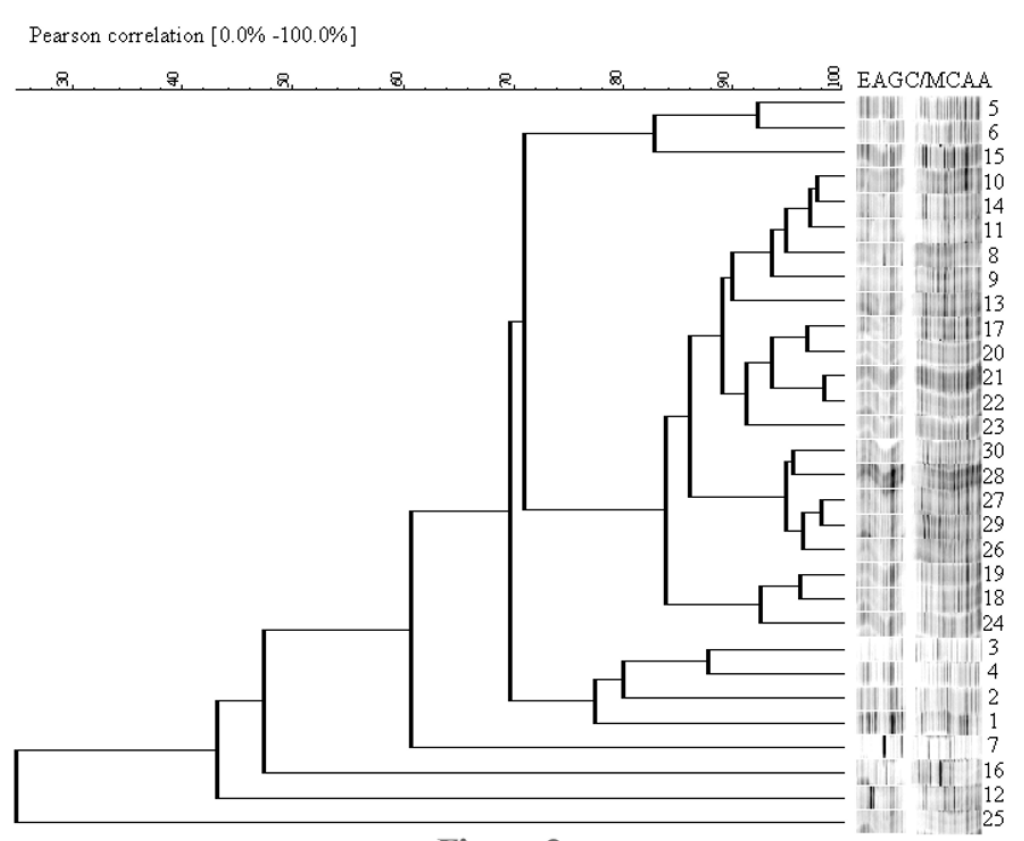

Figure 3a

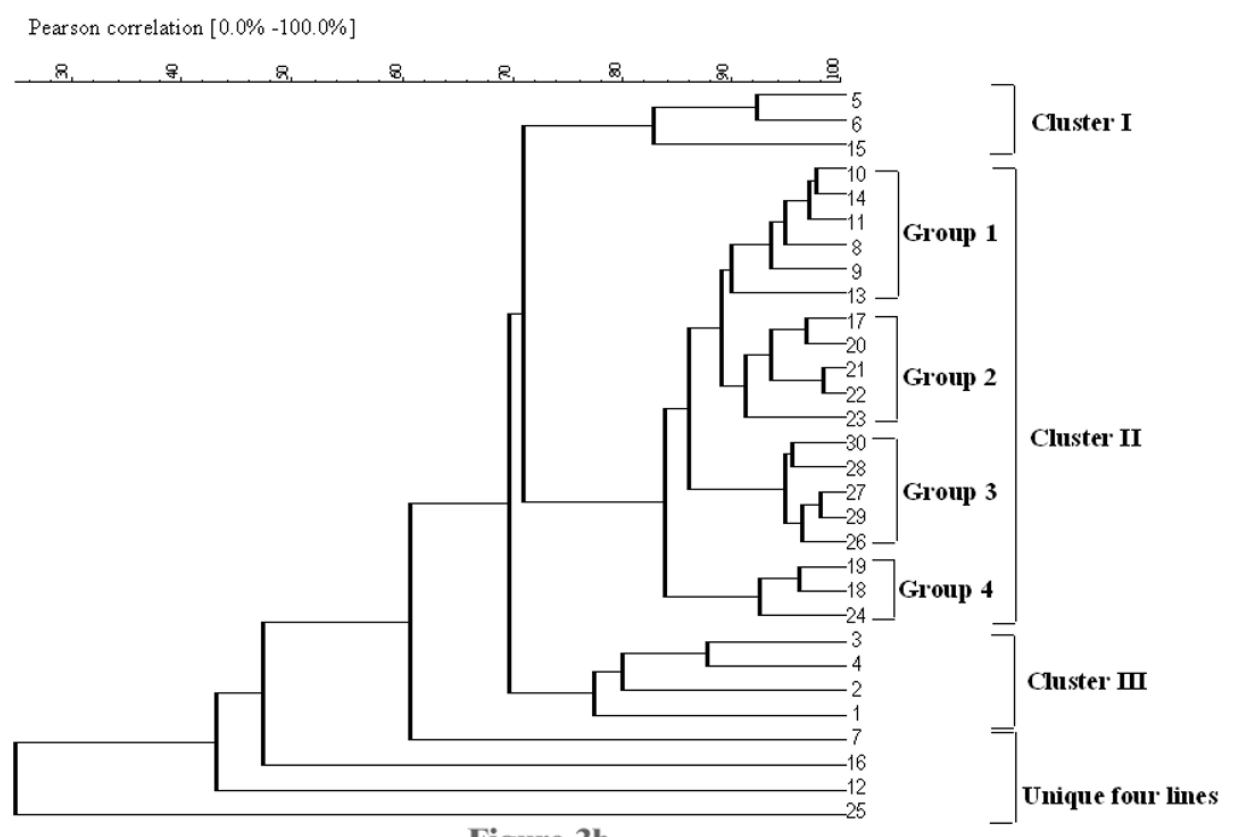

Figure 3b

UPGMA dendrograms. A: black pepper cultivars using AFLP analysis along with digital fingerprint profile. B: the clustering pattern obtained for the major cultivars of black pepper.

Figure 3

UPGMA dendrograms. A: black pepper cultivars using AFLP analysis along with digital fingerprint profile. B: the clustering pattern obtained for the major cultivars of black pepper. 
Table I: The details of the polymorphic pattern generated by three different primer combinations

\begin{tabular}{lccc}
\hline Primer pair & Total number of bands & Total number of polymorphic bands & Percentage of polymorphism \\
\hline EAGC/MCAA & 72 & 59 & 81.9 \\
EAGG/MCTA & 63 & 62 & 98.4 \\
EAGC/MCTG & 38 & 37 & 97.3 \\
\hline Total & 173 & 158 & 91.4 \\
\hline
\end{tabular}

(28) are all closely related (similarity $>70$ ). The Thevanmundi accessions are not as closely related, with Kuching/ Thevanmundi 12 having a similarity coefficient of 45.37 and Kuching/Thevanmundi 15 having a coefficient of 67.21. Kuching is the most popular cultivar in Malaysia. It is thought that black pepper was brought to Malaysia from Southern India by the Chinese trader Zheng, who organized a series of expeditions to the Malabar Coast, visiting numerous seacoasts on route [20].

\section{Discussion}

Piper nigrum L. has a high level of polymorphism (96.6\%) among the cultivars indicating extensive genetic variation of the Indian germplasm [21]. Pradeepkumar et al., 2003 [22] reports the increase in divergence among landraces, compared to the advanced cultivars, that have been derived mostly by clonal selection from land races, though a few are of hybrid origin. Morphologically divergent intraspecific variants of this species occur both in wild forms and in the cultivated varieties. These facts should be considered essentially to select diverse types in crossing programmes for improvement of breeding and while planning conservation strategies.

The AFLP profiles depend mainly on the selective base pairs in the primer, which are utilized to amplify the

Table 2: The descriptive characters of the major black pepper cultivars as provided by NBPGR, Thrissur

\begin{tabular}{|c|c|c|c|}
\hline S. No. & IC No. & Local names & Locality \\
\hline I & 85318 & Local a & Kuttampuzha \\
\hline 2 & 85319 & Local b & Karukachal \\
\hline 3 & 85320 & Karimunda & Puyamkutti \\
\hline 4 & 85321 & Local c & Puyamkutti \\
\hline 5 & 85322 & Local d & Patadi \\
\hline 6 & 85338 & Nedumundi & Ayiram Acre \\
\hline 7 & 85343 & Local e & Ayiram Acre \\
\hline 8 & 85352 & Local f & Nedunkandam \\
\hline 9 & 85354 & Vattamundi & Nedunkandam \\
\hline 10 & 85357 & Neelamundi & Nedunkandam \\
\hline 11 & 85361 & Vellamundi & Nedunkandam \\
\hline 12 & 85371 & Thevanmundi & Kumili \\
\hline 13 & 85375 & Narayakkodi & Peermed \\
\hline 14 & 85376 & Vellamundi & Peermed \\
\hline 15 & 85377 & Thevanmundi & Peermed \\
\hline 16 & 85387 & Karimunda & Thadiyanpad \\
\hline 17 & 85388 & Neelamundi & Thadiyanpad \\
\hline 18 & 85396 & Chomala & Mekkazhoor \\
\hline 19 & 85398 & Valiyaramunda & Perinadu \\
\hline 20 & 85401 & Valiyamunda & Kochandi \\
\hline 21 & 85402 & Palikkodi & Kochandi \\
\hline 22 & 85415 & Local g & Konni \\
\hline 23 & 85420 & Karinthakara & Konni \\
\hline 24 & 85422 & Arimani & Adoor \\
\hline 25 & 85424 & Konnamankara & Pandalam \\
\hline 26 & 85528 & Arivally & Panniyur \\
\hline 27 & 85533 & Kanjiramundi & Panniyur \\
\hline 28 & 85537 & Kottanadan & Panniyur \\
\hline 29 & 85538 & Kutching & Panniyur \\
\hline 30 & 85544 & Vokkale & Panniyur \\
\hline
\end{tabular}


EcoR1/MseI restriction digested DNA fragments. The selective base pairs in the primer correspond to the first base pairs of the genomic DNA beyond the restriction site. Changing these three selective base pairs in the primer can be used as a dynamic tool to scrutinize the genetic diversity within specific plant populations.

Fingerprint profiles generated were best with the three primer combinations EAGC/MCAA, EAGG/MCTA and EAGC/MCTG. In a similar study on Lettuce [23], 320 polymorphic loci were determined using only three AFLP primer combinations. In our study the mean number of bands created was highest (72) for primer pair EAGC/ MCAA, when compared to the other two combinations selected (EAGG/MCTA-63, EAGC/MCTG-38). Even though the primer pair EAGC/MCAA had greater number of scorable bands, the number of polymorphic bands was high for EAGG/MCTA-62/63; hence the percentage of polymorphism was maximum (98.74\%) for this primer pair selected. A comprehensive analysis was achieved when the individual dendrograms of each primer pair tested were compared with the composite dendrogram of all the chosen three primer pairs. The mean percentages of polymorphism of all the three primer combinations were found to be very high $(>90 \%)$. The majority of landraces were distinctly different from advanced cultivars in the molecular profile indicating artificial breeding efforts have brought distinct genetic changes in the species.

During the course of time, human migration from the plains to the hilly tracts of Western Ghats contributed to the spread of certain high yielding cultivars of black pepper. The cultivars were clonally propagated, identified and named by the farmers. These form the basis of the present day landraces in confined areas. Given this history, it is not surprising to find some possible discrepancies in the naming and identification of cultivars. AFLP analysis is an ideal tool for investigating genetic similarity among accessions from the germplasm collection and identifying the most divergent cultivars. AFLP analysis can also provide information on the uniqueness of the unnamed local cultivars.

\section{Conclusion}

Pepper, is a valuable spice crop. AFLP fingerprinting studies circumvents the traditional methods for identification of cultivars, which will take several years. Using incorrectly identified germplasm material for breeding programmes can produce misleading and unsuccessful results. As seen from the preliminary results, AFLP marker has the potential to provide solutions to the presence of duplicates in the collection of germplasm, misnaming of cultivars etc. Thus the data obtained, can also be utilized for further comparison and improvement of pepper cultivars, thereby ensuring a promising future by facilitating rational selection of parents from genetically divergent groups of cultivars. Linkage of genetic markers to specific commercial traits in future will assist plantation management strategies. All the observations support the view that pepper originated in the tropical evergreen forests of Western Ghats and that it is a species that is still in evolution.

\section{Methods \\ Plant material}

Thirty accessions of black pepper were obtained from the germplasm collection of National Bureau of Plant Genetic Resource (NBPGR), Thrissur. This represents the most popular widely cultivated landraces. The cultivars extend across the central, southern and northern parts of the state of Kerala (Table 2).

\section{DNA extraction}

From $1 \mathrm{~g}$ of young tender leaves of each black pepper cultivar, total genomic DNA was isolated, using Nucleon phtyopure plant DNA extraction kit (Amersham) according to manufacturer's instructions.

\section{AFLP analysis}

DNA fingerprints were generated according to the standard protocol using the AFLP kit (Invitrogen). For each sample, $0.5 \mu \mathrm{g}$ of DNA was restriction digested with $2.5 \mu \mathrm{g}$ of EcoRI/MseI restriction enzyme in a total reaction volume of $25 \mu \mathrm{l}$ and incubated at $37^{\circ} \mathrm{C}$ for $2 \mathrm{hrs}$. Samples were then transferred to $70^{\circ} \mathrm{C}$ bath for 15 min before being briefly cooled on ice to inactivate the enzyme. Digested DNA, was supplemented with $25 \mu \mathrm{l}$ of adapter solution (EcoRI/MseI adapters, $0.4 \mathrm{mM}$ ATP, $10 \mathrm{mM}$ Tris$\mathrm{HCl}$ (pH 7.5), $10 \mathrm{mM} \mathrm{Mg-acetate,} 50 \mathrm{mM} \mathrm{K}$-acetate) and $1 \mu \mathrm{l}$ of T4 DNA ligase and incubated at $20^{\circ} \mathrm{C}$ for $2 \mathrm{hrs}$. This was then diluted (1:10) with TE buffer. $5 \mu$ l of diluted ligation mix was combined with $40 \mu$ l of preamp primer mix, $5 \mu \mathrm{l}$ of $10 \times$ buffer plus $\mathrm{MgCl}_{2}$ and $5 \mu \mathrm{l}$ of Taq DNA polymerase in order to perform the pre selective amplification. PCR was performed for 20 cycles of $94^{\circ} \mathrm{C}$ for $30 \mathrm{~s}$, $56^{\circ} \mathrm{C}$ for $60 \mathrm{~s}$ and $72^{\circ} \mathrm{C}$ for $60 \mathrm{~s}$. Consequently the PCR amplification mixture was diluted (1:50) with TE buffer. For selective amplification, the EcoRI primer in each primer pair combination chosen was radiolabelled with $[\gamma$ 33P] ATP. About $18 \mu \mathrm{l}$ of EcoRI selective primer was labeled with $[\gamma$ 33P] ATP using $20 \mu \mathrm{l}$ of T4 polynucleotide kinase ( $50 \mathrm{mM}$ TrisHCl (pH 7.6), $25 \mathrm{mM} \mathrm{KCl}, 1 \mathrm{mM} \beta$ mercaptoethanol, $0.1 \mu \mathrm{M}$ ATP, $50 \%$ (v/v) glycerol) in $5 \times$ kinase buffer in a total reaction of $50 \mu \mathrm{l}$. Labeling was done at $37^{\circ} \mathrm{C}$ for $1 \mathrm{hr}$ and kept back at $70^{\circ} \mathrm{C}$ for $10 \mathrm{~min}$ for heat inactivation of enzymes. A 50 ul reaction comprising, $5 \mu \mathrm{l}$ each of diluted pre selective DNA sample, 5 $\mu$ l of radiolabelled EcoRI primer, $5 \mu$ l each of MseI primer, $20 \mu \mathrm{l}$ of $10 \times$ PCR buffers with $\mathrm{MgCl}_{2}$ and $5 \mu \mathrm{l}$ of Taq DNA polymerase, was subjected to a touch down PCR of 13 
cycles, which included $94^{\circ} \mathrm{C}$ for $30 \mathrm{~s}, 65^{\circ} \mathrm{C}$ for $30 \mathrm{~s}$ and $72^{\circ} \mathrm{C}$ for $60 \mathrm{~s}$. The annealing temperature were reduced by $0.7^{\circ} \mathrm{C}$ during these 13 cycles in an attempt to give a touchdown phase from $65^{\circ} \mathrm{C}$ to $56^{\circ} \mathrm{C}$. This was followed by 23 cycle reactions of $94^{\circ} \mathrm{C}$ for $30 \mathrm{~s}, 56^{\circ} \mathrm{C}$ for $30 \mathrm{~s}$ and $72^{\circ} \mathrm{C}$ for $60 \mathrm{~s}$. The amplification products were electrophoresed at constant power in a $6 \%$ denaturing polyacrylamide gel, to resolve the fragments until xylene cyanol run two-third down the length of the gel. The experiment was repeated to confirm the results. Later the gel was vacuum dried at $80^{\circ} \mathrm{C}$ for $1 \mathrm{hr}$ and developed using the phosphor imager (Biorad) after exposure for 3-4 hrs.

\section{Data analysis}

Each fingerprint profile was scored for the presence or absence of bands. Very faint bands were excluded and only the scorable, intense bands were used for further analysis. The fingerprint profile with the selected bands alone was further analysed by Bionumerics software package, version 3 (Applied maths, Belgium). A composite dendrogram (for the three primer combinations) and a Pearson correlation coefficient similarity matrix were generated based on the Unweighted Pair Group Method with Arithematic mean (UPGMA).

\section{Authors' contributions}

NJ conducted the experiments and participated in interpretation of results and manuscript preparation. EVS participated in the design of studies and in the discussion for preparing the manuscript and did the final revision. AZ provided the plant materials used for the study. All authors read and approved the final manuscript.

\section{Additional material}

\section{Additional file 1}

Similarity Matrix. a copy of the distance matrix of Figure 2 in the simple text file showing similarity value between the black pepper cultivars. Click here for file

[http://www.biomedcentral.com/content/supplementary/14712156-8-42-S1.doc]

\section{Acknowledgements}

The study was partially funded by Department of Biotechnology, New Delhi, INDIA.

\section{References}

I. Ravindran PN: Black pepper (Piper nigrum). Harwood academic publishers; 2000.

2. Mathew PM: Studies on Piperaceae. J Indian Bot Soc 1958, 37:155-171.

3. Mathew PM: Karyomorphological studies on Piper nigrum. Proc Natl Symp Plantation Crops 1972:15-18.

4. Jose J, Sharma AK: Chromosome studies in the genus Piper L. J Indian Bot Soc 1984, 63:313-319.
5. Vos P, Hogers R, Bleeker M, Reijans M, Lee TV, Hornes M, Frijters A, Pot J, Peleman J, Kupier M, Zabeau M: AFLP, a new technique for DNA fingerprinting. Nucl Acid Res 1995, 23:4407-44I4.

6. Balasaravanan T, Pius PK, Raj Kumar R, Muraleedharan N, Shasany AK: Genetic diversity among south Indian tea germplasm (Camellia sinensis, C.assamica and C.assamica spp.lasiocalyx) using AFLP markers. Plant Sci 2003, I65:365-372.

7. Negi MS, Sabharwal V, Bhat SR, Lakshmikumaran M: Utility of AFLP markers for the assessment of genetic diversity within Brassica nigra germplasm. Plant Breeding 2004, I 23(I): I3-16.

8. Rouppe van der Voort JN, van Zandvoort P, van Eck HJ, Folkertsma RT, Hutten RC, Draaistral J, Gommers FJ, Jacobsen E, Helder J, Bakker J: Use of allele specificity of comigrating AFLP markers to align genetic maps from different potato genotypes. Mol Gen Genet 1997, 255(4):438-47.

9. Ana LVB, Eberson SC, Isaias OG, Carlos AA: Genetic similarity among soybean (Glycine max (L) Merrill) cultivars released in Brazil using AFLP markers. Genet Mol Biol [online] 2006, 29(4):692-704.

10. Xiaoquan Q, Pim L: Development of AFLP markers in barley. Molecular and General Genetics 1997, 254:330-336.

II. Miroslaw T: A simplified AFLP method for fingerprinting of common wheat (Triticum aestivum L.) cultivars. J Appl Genet 2002, 43(2): |3|-| 43.

12. Saunders JA, Pedroni MJ, Daughtry CS: DNA fingerprinting of marijuana by the AFLP technique. Focus 1998, 20(Suppl): I0-II.

13. Brien SJ, Cowling WA, Potter RH, O' Brien, Jone RAC, Jones MGK: A molecular marker for early maturity $(K u)$ and marker assisted breeding of Lupinus anguustifolius. In Proceedings of the Australian Plant Breeding Conference, IIth, Adelaida, South Australian Research and Development Institute, Urrbrae, South Australia 1999, 1923:204-205.

14. Saunders JA, Pedroni MJ, Penrose LDJ, Fist AJ: AFLP analysis of opium poppy. Crop Sci 200I, 4I:I596-I60I.

15. Pradeepkumar T, Karihaloo JL, Archak S: Molecular characterization of Piper nigrum L cultivars using RAPD markers. Current Science 200I, 8I:3.

16. Penner GA, Bush A, Wise R, Kim W, Domier L, Kasha K, Laroche A, Scoles G, Molner SJ, Fedak G: Reproducibility of random amplified polymorphic DNA (RAPD) analysis among laboratories. PCR Meth Appl 1993, 2:34I-345.

17. Skroch P, Nienhuis J: Impact of scoring error and reproducibility of RAPD data on RAPD based estimates of genetic distance. Theor Appl Genet 1995, 91 : 1086-1091.

18. Ravindran PN, Balakrishnan R, Nirmal Babu K: Morphogenetic studies on black pepper I. Cluster analysis of black pepper cultivars. J Spices and Aromatic Crops 1997, 6:9-20.

19. Ravindran PN, Balakrishnan R, Nirmal Babu K: Morphometric studies on black pepper II. Principal component analysis of black pepper cultivars. J Spices and Aromatic Crops 1997, 6:21-29.

20. T'ien, Ju-K'ang : China and pepper trade. Hemisphere 1981:220-222.

21. Chaturvedi SN, Singh KP: Plant Reproductive and Molecular Biology 2005:164-174.

22. Pradeepkumar Y, Karihaloo JL, Archak S, Baldev A: Analysis of genetic diversity in Piper nigrum $L$. using RAPD markers. Genetic Resources and Crop Evolution 2003, 50(5):469-475.

23. Hill M, Witsenboer H, Zabeau M, Vos P, Kerseli R, Michelmore R: PCR based fingerprinting using AFLPs as a tool for studying genetic relationships in Lactuca spp. Theor Appl Genet 1996, 93: $1202-1210$. 